\title{
Study on NOx emissions from a national V heavy-duty diesel engine
}

\author{
Pi-qiang TAN\& Huan ZENG\& Zhi-yuan HU\& Di-ming LOU \\ School of Automobile, Tongji University, Shanghai, China
}

\begin{abstract}
KEYWORD: SCR; Diesel engine; pollution; Emissions; NOx; Detail components
ABSTRACT: Detail components of nitrogen oxides (NOx) emissions, which is including NO, NO2, and $\mathrm{N} 2 \mathrm{O}$, from a national V heavy-duty diesel engine with selective catalytic reduction (SCR) were studied under different operating conditions by using Fourier transform infrared spectrum (FTIR) technology. Results show that compared to the engine without SCR, descent of NOx emissions from the engine with SCR on different load are different and the higher load, the more drop. NO and NO2 emissions from the engine with SCR have an varying degrees of decline, $\mathrm{N} 2 \mathrm{O}$ emissions raise more than $50 \%$ as a result of SCR side reaction exists. $22 \mathrm{O}$ emissions ascends with the increase of the load, and this is because increasing exhaust temperature leads to higher oxidation reaction rate of $\mathrm{NH} 3$ to $\mathrm{N} 2 \mathrm{O}$.
\end{abstract}

\section{INTRODUCTION}

Nitrogen oxide (NOx) is important exhaust emissions of diesel engine, and its detailed components including $\mathrm{NO}, \mathrm{NO}_{2}$, and $\mathrm{N}_{2} \mathrm{O}^{[1-3]}$. High concentrations of $\mathrm{NO}$ can cause human neural disorder, $\mathrm{NO}$ will generate the nitrite in human body, and it would cause hypoxia by integrating with hemoglobin in the blood. $\mathrm{NO}$ will become $\mathrm{NO}_{2}$ quickly in air, and $\mathrm{NO}_{2}$ is one of the sources of acid rain and one of the important cause of photochemical smog, it also poisons the body's respiratory system ${ }^{[4]} \cdot \mathrm{N}_{2} \mathrm{O}$ is an important greenhouse gas, its greenhouse effect as 300 times much as $\mathrm{CO}_{2}{ }^{[5-6]}$.

The use of ammonia-based selective catalytic reduction is an important method for reducing heavy diesel engine NOx to meet the national $\mathrm{V}$ diesel engine emissions standards ${ }^{[7,8]}$. It may cause $\mathrm{NH}_{3}$ leak in the process of using selective catalytic reduction (SCR). $\mathrm{NH}_{3}$ will cause human ammonia poisoning and inhibit the central nervous system. Our country stipulates the average $\mathrm{NH}_{3}$ emissions should not more than $25 \times 10^{-6}$ in the transient ETC emissions test cycle of heavy duty diesel engine [9].

Generally speaking, $\mathrm{NO}$ is main ingredients of $\mathrm{NOx}, \mathrm{NO}_{2}$ is secondary components, and $\mathrm{N}_{2} \mathrm{O}$ is very small amounts, and so on. Pi-qiang Tan studied the effects of engine load on emissions of $\mathrm{NO}_{2}$ under different fuel injection advance angle and speed, he found that $\mathrm{NO}_{2} / \mathrm{NOx}$ radio has a significant reduction with the increase of engine load ${ }^{[1]}$. Tang Tao studied $\mathrm{N}_{2} \mathrm{O}$ formation characteristics under different diesel engine aftertreatment systems, he found that SCR which contained $\mathrm{Cu}$ zeolite catalyst and $\mathrm{Cu} / \mathrm{Fe}$ composite catalysts, $\mathrm{N}_{2} \mathrm{O}$ production showed a trend of decreases after increase and then increase with the rise of temperature ${ }^{[10]}$. Klimczak found that redox reaction of NO can produce $\mathrm{N}_{2} \mathrm{O}$ in the $\mathrm{SCR}^{[11]}$. Pan Li studied redox reaction of $\mathrm{NO}$ in $\mathrm{V}_{2} \mathrm{O}_{5} \mathrm{SCR}$, he found that $\mathrm{N}_{2} \mathrm{O}$ increases with the rise of temperature ${ }^{[12]}$.

From the above literature, we can see that the NOx component have carried out some research in existing public literatures, but it is too few that the system research about the emissions characteristics of NOx detailed components $\left(\mathrm{NO}, \mathrm{NO}_{2}, \mathrm{~N}_{2} \mathrm{O}\right)$ and $\mathrm{NH}_{3}$ in diesel engine equipped with SCR.

Because of this reason, the paper carried out tests on a national $\mathrm{V}$ heavy-duty diesel engine, diesel engine exhaust $\mathrm{NOx}$ detailed components $\mathrm{NO}, \mathrm{NO}_{2}, \mathrm{~N}_{2} \mathrm{O}$ and $\mathrm{NH}_{3}$ were studied by using Fourier transform infrared spectrometer (FTIR), and emissions characteristics of NOx detailed components of heavy-duty diesel engine with SCR and without SCR were explores.

\section{Experimental Setup}

\section{Engine, SCR and FTIR}

In this paper, the research object is a national $\mathrm{V}$ heavy-duty diesel engine with electronically controlled and high pressure common rail. The main specifications of the test engine were shown in table 1 . 
Table 1. Main Specifications of test engine

\begin{tabular}{lc}
\hline Items & Parameters \\
\hline Displacement & 8.82L \\
Cylinder type & 6 cylinders line-engine, 4 valves \\
Type & Inter-cooling turbo \\
Bore/Stroke & $114 \mathrm{~mm} / 144 \mathrm{~mm}$ \\
Ratio & $18: 1$ \\
Rated power & $184 \mathrm{~kW}(2200 \mathrm{r} / \mathrm{min})$ \\
Max torque & $1000 \mathrm{~N} \cdot \mathrm{m}(1400 \mathrm{r} / \mathrm{min})$ \\
\hline
\end{tabular}

In figures of this paper, the engine without SCR referred to as original, and the engine with $\mathrm{SCR}$ referred to as $\mathrm{SCR}$. V-W/TiO 2 is main SCR catalyst of this experiment. Main Specifications of the SCR were shown in table 2.

Table 2. Main Specifications of SCR

\begin{tabular}{lc}
\hline Items & Parameters \\
\hline Length of catalytic converter & $660.4 \mathrm{~mm}$ \\
Diameter of catalytic converter & $152.4 \mathrm{~mm}$ \\
Stable operation range & $180 \sim 600^{\circ} \mathrm{C}$ \\
Urea pump spray range & $0 \sim 8000 \mathrm{ml} / \mathrm{h}$ \\
\hline
\end{tabular}

The emissions of engine without SCR and engine with SCR were measured by AVL FTIR. FTIR is based on Raman Effect through the interferometer interference frequency modulation. To gain spectra, the interference figure is measured and interference figure Fourier transforms is carried out according to the corresponding relationship between interferogram and spectra. And the corresponding groups of atoms or groups of atoms combine information were gained by compared with standard atlas, then the concentration of the quantitative analyst is of the components can be done according to Bill Law ${ }^{[13,14]}$.

\section{Experiment Procedure}

The heavy-duty diesel engine $\mathrm{NOx}$ detailed component $\left(\mathrm{NO}, \mathrm{NO}_{2}, \mathrm{~N}_{2} \mathrm{O}\right)$ and $\mathrm{NH}_{3}$ emissions characteristics were studied, test point is present as follows:

Two speeds were choose, respectively for the maximum torque speed $1400 \mathrm{r} / \mathrm{min}$, the rated power speed $2200 \mathrm{r} / \mathrm{min}$, those speed by $10 \%, 25 \%, 50 \%, 25 \%$ and $100 \%$ load, a total of 10 point.

The mass concentration of the tested urea solution wis $32.5 \%$, which is the standard urea solution used by car. To provide enough ammonia, urea basic injection quantity will be set to 1.2 times as much as the amount of NOx completely reaction in theory, namely the complete decomposition of urea solution produced by the molar ratio of $\mathrm{NH}_{3}$ and $\mathrm{NOx}$ is equal to 1.2:1.

\section{RESULTS AND DiSCUSSION}

\section{The average temperature and exhaust flow}

NOx production is related to average temperature and exhaust flow of catalytic converter, so it is necessary to studied them.

Figure 1 shows that the average temperature and exhaust flow. It can be seen that average temperature and exhaust flow of catalytic converter were significantly increased with the increase of load at $1400 \mathrm{r} / \mathrm{min}$ and $2200 \mathrm{r} / \mathrm{min}$. And under the same load, average temperature of $1400 \mathrm{r} / \mathrm{min}$ significantly higher than that of $2200 \mathrm{r} / \mathrm{min}$, but the exhaust flow rate of $1400 \mathrm{r} / \mathrm{min}$ is lower than $2200 \mathrm{r} / \mathrm{min}$. 


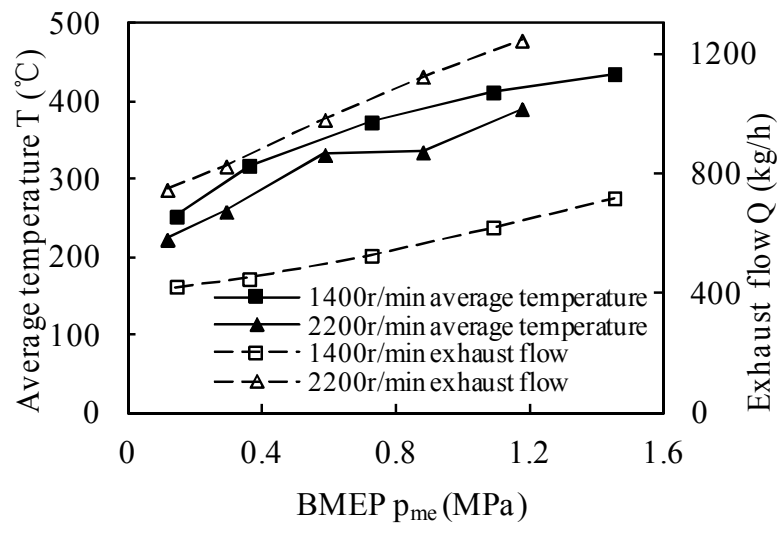

Figure 1. Average temperature and exhaust flow of SCR catalysts

\section{Detail Components of NOx}

Figure 2 shows that NOx emissions under different load. In original engine, NOx emissions were raising with the increase of load, and NOx emissions of $1400 \mathrm{r} / \mathrm{min}$ is higher than that of $2200 \mathrm{r} / \mathrm{min}$. After adding SCR, compared with the original engine, NOx emissions has varying degrees of decline, but its rule of change is not obvious with the increase of load. After adding SCR, NOx emissions of $1400 \mathrm{r} / \mathrm{min}$ has an average decreased by $67.7 \%$ and biggest decreased by $92.9 \%$, which appears in the region of the high load. At this load, exhaust temperature is high, SCR catalyst activity is strong, NOx emissions decline significantly. The smallest decline is $30.8 \%$ in small load area, where exhaust gas temperature is lower. After adding SCR, NOx emissions of $2200 \mathrm{r} / \mathrm{min}$ has an average decreased by $87.6 \%$ and biggest decreased by $97.1 \%$, which appears in the region of the middle load. At this load, NOx emissions of the original engine were not very high, but its high exhaust temperature, SCR catalyst activity is strong, NOx emissions decline significantly. The smallest decline of 2200 $\mathrm{r} / \mathrm{min}$ is $60.4 \%$ in the small load where exhaust gas temperature is low.

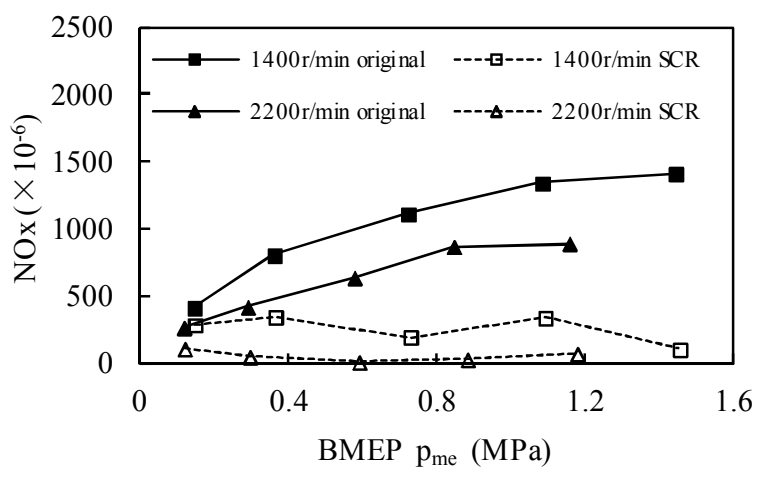

Figure 2. NOx emissions

\section{NO Emissions}

Figure 3 shows that NO emissions under different load. In original engine, NO emissions is rising with the increase of load, and NO emissions of $1400 \mathrm{r} / \mathrm{min}$ is higher than that of $2200 \mathrm{r} / \mathrm{min}$. This is mainly due to temperature in cylinder of $1400 \mathrm{r} / \mathrm{min}$ is higher than that of $2200 \mathrm{r} / \mathrm{min}$. After adding SCR, NO emissions has decrease sharply compared with the original engine, but its rule of change is not obvious with the increase of load. NO emissions of $1400 \mathrm{r} / \mathrm{min}$ has an average decreased by $68.2 \%$ and biggest decreased by $94.1 \%$. NO emissions of $2200 \mathrm{r} / \mathrm{min}$ has an average decreased by $87.4 \%$ and biggest decreased by $97.7 \%$. 


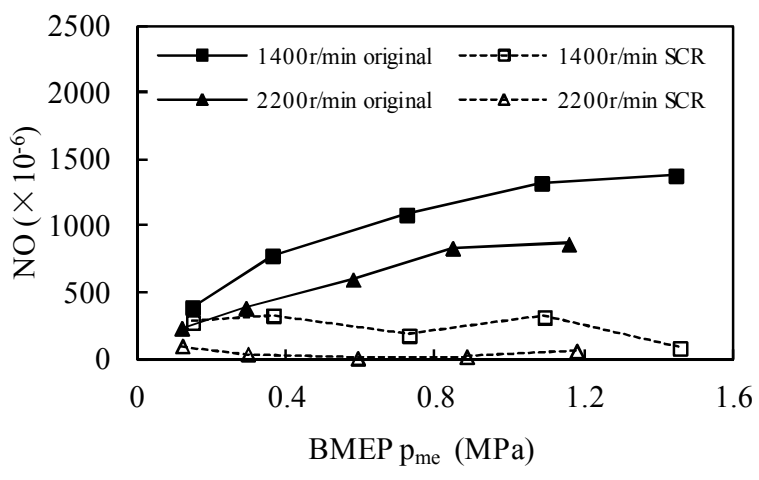

Figure 3. NO emissions

\section{$\mathrm{NO}_{2}$ Emissions}

Figure 4 shows that $\mathrm{NO}_{2}$ emissions under different load. In original engine, $\mathrm{NO}_{2}$ emissions of 1400 $\mathrm{r} / \mathrm{min}$ ascends firstly and then decline with the improvement of mean effective pressure, and then increase around $1 \mathrm{MPa} . \mathrm{NO}_{2}$ emissions of $2200 \mathrm{r} / \mathrm{min}$ ascends firstly and then decline with the increase of the mean effective pressure.

After adding SCR, $\mathrm{NO}_{2}$ emissions has fallen sharply compared with the original engine. $\mathrm{NO}_{2}$ emissions of $1400 \mathrm{r} / \mathrm{min}$ is on the rise roughly with the increase of the mean effective pressure, $\mathrm{NO}_{2}$ emissions of $2200 \mathrm{r} / \mathrm{min}$ change smaller with the increase of the mean effective pressure, emissions are mostly around $3 \times 10^{-6}$.

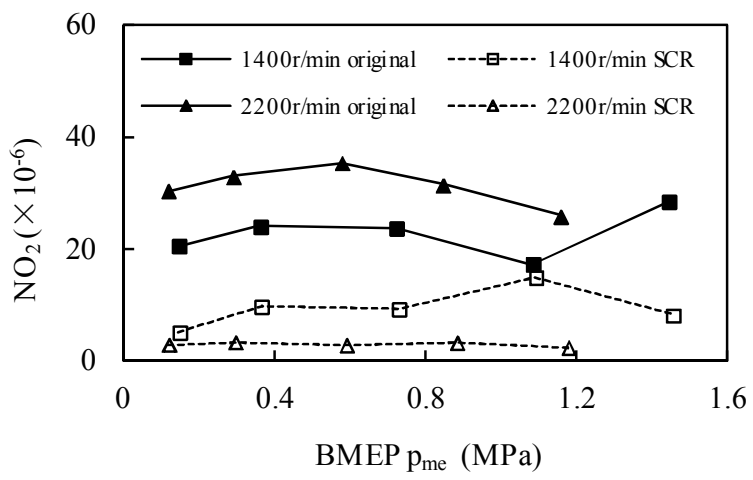

Figure 4. $\mathrm{NO}_{2}$ emissions

It is important to note that $\mathrm{NO}_{2}$ emissions of $2200 \mathrm{r} / \mathrm{min}$ more than $1400 \mathrm{r} / \mathrm{min}$ in the original engine, but after adding SCR, $\mathrm{NO}_{2}$ emissions of $2200 \mathrm{r} / \mathrm{min}$ less than $1400 \mathrm{r} / \mathrm{min}$. After adding SCR, $\mathrm{NO}_{2}$ emissions of $1400 \mathrm{r} / \mathrm{min}$ has an average decreased by $56.6 \%$ and biggest decreased by $75.6 \%$ compared to the original engine. $\mathrm{NO}_{2}$ emissions of $2200 \mathrm{r} / \mathrm{min}$ has an average decreased by $90.9 \%$ and biggest decreased by $92.3 \%$. The main reason is that $\mathrm{NH}_{3}$-based SCR have different reaction under different conditions ${ }^{[15-17]}$ : standard SCR reaction and rapid SCR reaction.

Standard SCR reaction is mainly catalytic reduction reaction between $\mathrm{NH}_{3}$ and $\mathrm{NOx}$, it has higher rate of reaction at $300{ }^{\circ} \mathrm{C} \sim 400^{\circ} \mathrm{C}$, reaction rate will lower when the temperature is lower, the reaction is as follows:

$4 \mathrm{NH}_{3}+4 \mathrm{NO}+\mathrm{O}_{2} \rightarrow 4 \mathrm{~N}_{2}+6 \mathrm{H}_{2} \mathrm{O}$

The rate of reaction (1) is slow relatively, when the radio of $\mathrm{NO} / \mathrm{NO}_{2}$ rising, $\mathrm{NO}_{2} / \mathrm{NO}$ radio to 1 at someplace, there is a more ideal reaction process, namely rapid SCR reaction, it can be working under the low temperature. The reaction is as follows:

$4 \mathrm{NH}_{3}+2 \mathrm{NO}+2 \mathrm{NO}_{2} \rightarrow 4 \mathrm{~N}_{2}+6 \mathrm{H}_{2} \mathrm{O}$

Figure 5 shows that $\mathrm{NO}_{2} / \mathrm{NO}$ ratio of original engine under different load. $\mathrm{NO}_{2} / \mathrm{NO}$ ratio of 1400 $\mathrm{r} / \mathrm{min}$ has fallen with the increase of load, it means that rapid SCR reaction reduces, standard SCR reaction increases, the reduction of $\mathrm{NO}_{2}$ decreases, and $\mathrm{NO}_{2}$ emissions of original engine don't change much, so the range of $\mathrm{NO}_{2}$ emissions decline isn't big after adding SCR. 


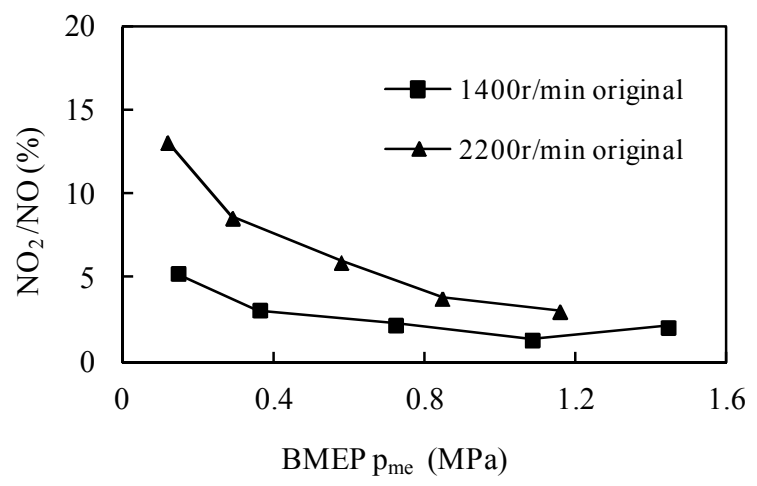

Figure $5 . \mathrm{NO}_{2} / \mathrm{NO}$ ratio without $\mathrm{SCR}$ at different load

\section{$\mathrm{N}_{2} \mathrm{O}$ Emissions}

Figure 6 shows that $\mathrm{N}_{2} \mathrm{O}$ emissions under different load. With the improvement of mean effective pressure, the original engine $\mathrm{N}_{2} \mathrm{O}$ emissions don't change much. $\mathrm{N}_{2} \mathrm{O}$ emissions of $1400 \mathrm{r} / \mathrm{min}$ is mainly about $2.0 \times 10^{-6}$, while it is mainly about $2.5 \times 10^{-6}$ of $2200 \mathrm{r} / \mathrm{min}$. After adding SCR, $\mathrm{N}_{2} \mathrm{O}$ emissions has raised sharply compared with the original engine. With the increase of mean effective pressure, $\mathrm{N}_{2} \mathrm{O}$ emissions of $1400 \mathrm{r} / \mathrm{min}$ and $2200 \mathrm{r} / \mathrm{min}$ were on the rise. Considering that the greenhouse effect of $\mathrm{N}_{2} \mathrm{O}$ is about 300 times of carbon dioxide, $\mathrm{N}_{2} \mathrm{O}$ emissions should bring to the forefront after adding SCR.

After adding SCR, $\mathrm{N}_{2} \mathrm{O}$ emissions is increased sharply compared to the original engine, this is mainly due to the reaction of SCR in addition to the normal reaction (1) and (2), there are side effects occur under high temperature, those reactions will produce $\mathrm{N}_{2} \mathrm{O}^{[18,19]}$ :

$$
\begin{aligned}
& 2 \mathrm{NH}_{3}+2 \mathrm{O}_{2} \rightarrow \mathrm{N}_{2} \mathrm{O}+3 \mathrm{H}_{2} \mathrm{O} \\
& 4 \mathrm{NH}_{3}+4 \mathrm{NO}+3 \mathrm{O}_{2} \rightarrow 4 \mathrm{~N}_{2} \mathrm{O}+6 \mathrm{H}_{2} \mathrm{O}
\end{aligned}
$$

At the same time, because of using urea as a reducing agent of SCR reactions, there is side effects might generate $\mathrm{NH}_{4} \mathrm{NO}_{3}$, if it is attached in the surface of the SCR, part of $\mathrm{NH}_{4} \mathrm{NO}_{3}$ occur decomposition to generate the $\mathrm{N}_{2} \mathrm{O}$ at low temperature ${ }^{[19,20]}$ :

$$
\mathrm{NH}_{4} \mathrm{NO}_{3} \rightarrow \mathrm{N}_{2} \mathrm{O}+2 \mathrm{H}_{2} \mathrm{O}
$$

It is important to note that $\mathrm{N}_{2} \mathrm{O}$ emissions of $1400 \mathrm{r} / \mathrm{min}$ is less than that of $2200 \mathrm{r} / \mathrm{min}$ in original engine, but after adding SCR, $\mathrm{N}_{2} \mathrm{O}$ emissions of $1400 \mathrm{r} / \mathrm{min}$ is more than that of $2200 \mathrm{r} / \mathrm{min}$. After adding SCR, $\mathrm{N}_{2} \mathrm{O}$ emissions of $2200 \mathrm{r} / \mathrm{min}$ has an average increase by $61.9 \%$ and biggest increase by $83.1 \%$ compared with original engine, $\mathrm{N}_{2} \mathrm{O}$ emissions of $1400 \mathrm{r} / \mathrm{min}$ has an average increase by 2.23 times and biggest increase by 3.29 times.

It is result of comprehensive action among the reaction (3), (4) and (5). After adding SCR, N2O emissions of $2200 \mathrm{r} / \mathrm{min}$ ascends firstly and then decline with the improvement of mean effective pressure, this is due to the exhaust temperature of $2200 \mathrm{r} / \mathrm{min}$ is lower than $1400 \mathrm{r} / \mathrm{min}$, the $\mathrm{N}_{2} \mathrm{O}$ under low load is mainly generated by the decomposition of $\mathrm{NH}_{4} \mathrm{NO}_{3}$, which mainly comes from the reaction (5). $\mathrm{NH}_{4} \mathrm{NO}_{3}$ decomposition will increase with temperature increasing properly, and when the exhaust temperature increased to a certain temperature, the generation of $\mathrm{NH}_{4} \mathrm{NO}_{3}$ decrease, $\mathrm{N}_{2} \mathrm{O}$ emissions becomes down. And when the exhaust temperature continues to raise, reaction (3) and (4) increase, so the $\mathrm{N}_{2} \mathrm{O}$ emissions continue to rise again. $\mathrm{N}_{2} \mathrm{O}$ emissions of $1400 \mathrm{r} / \mathrm{min}$ rise with the increase of the load, this is mainly due to the average effective pressure increase, the exhaust temperature increased, $\mathrm{NH}_{4} \mathrm{NO}_{3}$ generation decreases, reaction (5) decreases, but it is increased that $\mathrm{NH}_{3}$ is oxidized into $\mathrm{N}_{2} \mathrm{O}$ by $\mathrm{NO}_{2}$ or $\mathrm{O}_{2}$, the reaction (3) and (4) increase significantly, so the $\mathrm{N}_{2} \mathrm{O}$ emissions rise gradually, and because exhaust gas temperature of $1400 \mathrm{r} / \mathrm{min}$ is higher than 2200 $\mathrm{r} / \mathrm{min}$, N2O emissions is generated more than $2200 \mathrm{r} / \mathrm{min}$ by reaction (3) and (4). 


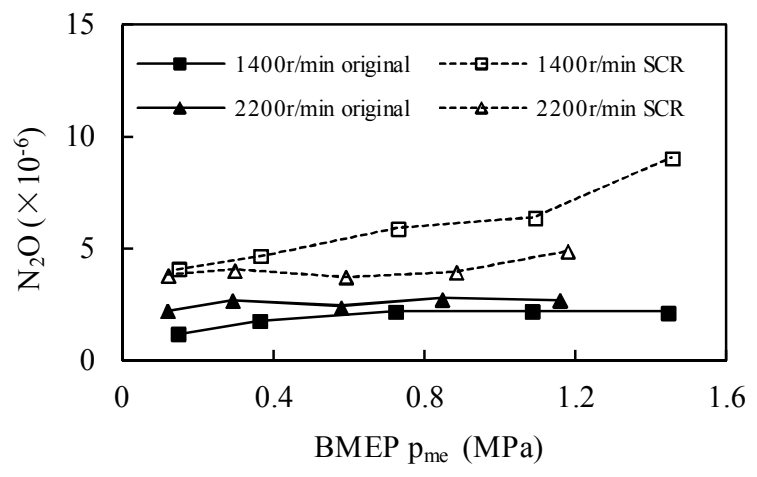

Figure 6. $\mathrm{N}_{2} \mathrm{O}$ emissions

\section{Conclusions}

Detail components of $\mathrm{NOx}$ emissions including $\mathrm{NO}, \mathrm{NO}_{2}$, and $\mathrm{N}_{2} \mathrm{O}$ from a national $\mathrm{V}$ heavy-duty diesel engine with SCR were studied by using FTIR technology. Main conclusions are as follows:

(1) In original engine, with the increase of the load, NO emissions continues to raise, $\mathrm{NO}_{2}$ emissions ascends firstly and then decline, $\mathrm{N}_{2} \mathrm{O}$ emissions is rare.

(2) Compared with the original engine, NOx emissions of diesel engine with SCR have varying degrees of decline, the drop of high load is more ideal.

(3) After adding SCR, $\mathrm{NO}$ and $\mathrm{NO}_{2}$ emissions were lower significantly, $\mathrm{NO}_{2}$ emissions decreases significantly under the rated speed. It is due to the slightly higher $\mathrm{NO}_{2} / \mathrm{NO}$ radio cause of SCR reaction more quickly.

(4) The $\mathrm{N}_{2} \mathrm{O}$ emissions from the engine with SCR is more than $50 \%$ the emissions from the engine without SCR, particularly higher under the maximum torque speed at full load, and this is because the SCR side reaction exists. $\mathrm{N}_{2} \mathrm{O}$ emissions is rising with the increase of the load, the main reason is high temperature lead $\mathrm{N}_{2} \mathrm{O}$ generation rate increases by $\mathrm{NH}_{3}$ oxidation reaction.

\section{REFERENCES}

[1] Piqiang TAN, Jiaxiang LU, Kangyao DENG, et al. 2003.Emission characteristic of nitrogen oxides from a direct injection diesel engine. Transactions of CSICE 21(6): 435-439

[2] Yue Peng, Junhua Li, Wenzhe Si. 2015. Deactivation and regeneration of a commercial SCR catalyst: comparison with alkali metals and arsenic. Applied Catalysis B: Environmental 168: $195-202$

[3] Jun Yu, Zhichun Si, Lei Chen, et al. 2015.Selective catalytic reduction of NOx by ammonia over phosphate-containing $\mathrm{Ce}_{0.75} \mathrm{Zr}_{0.25} \mathrm{O}_{2}$ solids. Applied Catalysis B: Environmental, 163: 223-232

[4] Fredrik R Westlye., Anders Ivarsson, Jesper Schramm. 2014. Experimental investigation of nitrogen based emissions from an ammonia fueled SI-engine. Fuel 111: 239-247

[5] Choong-Kil Seo, Hwanam Kim, Byungchul Choi, et al. 2011. De-NOx characteristics of a combined system of LNT and SCR catalysts according to hydrothermal aging and sulfur poisoning. Catalysis Today 164: 507-514

[6] Cristina Campa Maria, Daniela Pietrogiacomia, Manlio Occhiuzzia. 2015. The simultaneous selective catalytic reduction of $\mathrm{N}_{2} \mathrm{O}$ and $\mathrm{NOx}$ with $\mathrm{CH} 4$ on Co- and Ni-exchanged mordenite. Applied Catalysis B: Environmental 168:293-302

[7] Lei Ma, Yisun Cheng, Giovanni Cavataio, et al. 2014. In situ DRIFTS and temperatureprogrammed technology study on $\mathrm{NH}_{3}-\mathrm{SCR}$ of NOx over $\mathrm{Cu}-\mathrm{SSZ}-13$ and $\mathrm{Cu}-\mathrm{SAPO}-34$ catalysts. Applied Catalysis B: Environmental 156-157: 428-437

[8] Sebastian Fogel, Pär Gabrielsson. 2014. $\mathrm{H}_{2}$-assisted $\mathrm{NH}_{3}-\mathrm{SCR}$ over $\mathrm{Ag} / \mathrm{Al}_{2} \mathrm{O}_{3}$ : An engine-bench study. Applied Catalysis B: Environmental 158-159: 1-10

[9] Ministry of Environmental Protection of the People's Republic of China. HJ437-2008.2008. Technical specification for on-board diagnostic (OBD) system of compression ignition and gas fuelled positive ignition engines of vehicles.

[10] Tao Tang, Jun Zhang, Shijin Shuai, et al. 2014. An experimental study on the $\mathrm{N}_{2} \mathrm{O}$ emission characteristics of diesel engine aftertreatment system. Automotive Engineering 36(10): 1193-1196

[11] M Klimczak, P Kern, T Heinzelmann, et al. 2010. High- throughput study of the effects of inorganic additives and poisons on $\mathrm{NH}_{3}-\mathrm{SCR}$ catalysts-Part $\mathrm{I}$ : $\mathrm{V}_{2} \mathrm{O}_{5}-\mathrm{WO}_{3} / \mathrm{TiO}_{2}$ catalysts. Applied Catalysis B: Environmental 95: 39-47

[12] Pan Li, Qingya Liu, Zhenyu Liu. 2011. $\mathrm{N}_{2} \mathrm{O}$ and $\mathrm{CO}_{2}$ formation during selective catalytic reduc- 
tion of $\mathrm{NO}$ with $\mathrm{NH}_{3}$ over $\mathrm{V}_{2} \mathrm{O}_{5} / \mathrm{AC}$ catalyst. Industrial \& Engineering Chemistry Research 50: 1906-1910

[13] Luis F Bobadilla, Olivier Marie, Philippe Bazin, et al. 2013. Effect of Pd addition on the efficiency of a NOx-trap catalyst: A FTIR operando study. Catalysis Today 205:24-33

[14] Piqiang Tan, Zhiyuan Hu, Diming Lou. 2012. FTIR detection of unregulated emission from a diesel engine with biodiesel fuel. Spectroscopy and Spectral Analysis 32(2): 360- 363

[15] Kurnia Wijayantia, Stanislava Andonova, Ashok Kumar. 2015. Impact of sulfur oxide on $\mathrm{NH}_{3}-$ SCR over Cu-SAPO-34. Applied CatalysisB:Environmental 167:568-579

[16] Jin Wang, Yaying Ji, Zhengwang He, et al. 2012. A non- $\mathrm{NH}_{3}$ pathway for $\mathrm{NOx}$ conversion in coupled LNT-SCR systems. Applied Catalysis B: Environmental 111: 562- 570

[17] Hui Zhang, Junmin Wang, Yue-Yun Wang. 2015. Removal of NOx sensor ammonia cross sensitivity from contaminated measurements in diesel-engine selective catalytic reduction systems. Fuel 150: 448-456

[18] Shijian Yang, Shangchao Xiong, Yong Liao, et al. 2014. Mechanism of $\mathrm{N}_{2} \mathrm{O}$ formation during the low-temperature selective catalytic reduction of $\mathrm{NO}$ with $\mathrm{NH}_{3}$ over Mn-Fe Spinel. Environmental Science \& Technology 48(17): 10354-10362

[19] Sachi Shrestha, Michael P Harolda, Krishna Kamasamudram, et al. 2014.Selective oxidation of ammonia on mixed and dual-layer Fe-ZSM-5 $+\mathrm{Pt} / \mathrm{Al}_{2} \mathrm{O}_{3}$ monolithic catalysts. Catalysis Today 231: $105-115$

[20] Lei Chen, Zhichun Si, Xiaodong Wu, et al. 2015. Effect of water vapor on $\mathrm{NH}_{3}-\mathrm{NO} / \mathrm{NO}_{2} \mathrm{SCR}$ performance of fresh and aged $\mathrm{MnOx}-\mathrm{NbOx}-\mathrm{CeO}_{2}$ catalysts. Journal of environmental sciences 31:240-247 